\title{
ISOLATION AND IDENTIFICATION OF MICROORGANISMS DURING SPONTANEOUS FERMENTATION OF MAIZE
}

\author{
[Isolasi dan Identifikasi Mikroorganisme pada Fermentasi Spontan Jagung]
}

\author{
Rahmawati ${ }^{1,2)}$, Ratih Dewanti-Hariyadi ${ }^{1,3)^{*}}$, Purwiyatno Hariyadi ${ }^{1,3)}$, Dedi Fardiaz ${ }^{1,3)}$ and Nur Richana ${ }^{4)}$ \\ 1) Department of Food Science and Technology, Bogor Agricultural University, Kampus IPB Darmaga, Bogor, Indonesia \\ 2) Department of Food Technology, Sahid University, Jakarta, Indonesia \\ 3) Southeast Asia Food Agricultural Science and Technology (SEAFAST) Center, Bogor Agricultural University, \\ Kampus IPB Darmaga, Bogor, Indonesia \\ 4) Indonesian Center for Agricultural Post Harvest Research \& Development (ICAPRD), Bogor, Indonesia
}

Accepted April 05 2013 / Approved June $12^{\text {th }} 2013$

\begin{abstract}
Maize was traditionally the second most common staple food in Indonesia. Conversion to maize flour has been accomplished to improve its convenience. Traditionally, maize flour is produced by soaking the kernels in water followed by grinding. It was reported that final physicochemical characteristics of the maize flour were influenced by spontaneous fermentation which occurred during soaking. This research aimed to isolate and identify important microorganisms that grew during fermentation thus a standardized starter culture can be developed for a more controlled fermentation process. Soaking of maize grits was conducted in sterile water (grits:water=1:2, w/v) in a closed container at room temperature $\left( \pm 28^{\circ} \mathrm{C}\right)$ for 72 hours. After $0,4,12,24,36,48,72$ hours, water and maize grits were sampled and tested for the presence of mold, yeast, and lactic acid bacteria $(\mathrm{LAB})$. Isolates obtained from the spontaneous fermentation were reinoculated into the appropriate media containing starch to observe their amylolytic activity. Individual isolate was then identified; mold by slide culture method, while yeast and LAB by biochemical rapid kits, i.e. API 20C AUX and API CH50, respectively. The number of each microorganism was plotted against time to obtain the growth curve of the microorganisms during spontaneous fermentation. The microorganisms were identified as Penicillium chrysogenum, $P$. citrinum, $A$. flavus, A. niger, Rhizopus stolonifer, R.oryzae, Fusarium oxysporum, Acremonium strictum, Candida famata, Kodamaea ohmeri, Candida krusei/incospicua, Lactobacillus plantarum 1a, Pediococcus pentosaceus, L. brevis 1, L. plantarum 1b, and L. paracasei ssp paracasei 3 . Four molds and one yeast were amylolytic while none of the LAB was capable of starch hydrolysis. The growth curve suggested that the amylolitic mold and yeast grew to hydrolyze starch during the course of fermentation, while the LABs benefited from the hydrolyzed products and dominated the later stage of the fermentation.
\end{abstract}

Keywords: amylolytic, LAB, maize, mold, spontaneous fermentation, yeast

\section{ABSTRAK}

Jagung merupakan makanan pokok kedua terpenting di Indonesia dan berbagai upaya telah dilakukan untuk memproduksi tepung jagung guna meningkatkan kemudahan penggunaannya. Secara tradisional, tepung jagung dibuat dengan merendam biji jagung dalam air, diikuti dengan proses penggilingan. Selama perendaman terjadi fermentasi spontan yang telah dilaporkan dapat mempengaruhi karakteristik fisiko kimia tepung jagung yang dihasilkannya. Penelitian ini bertujuan untuk mengisolasi dan mengidentifikasi mikroba penting yang tumbuh selama fermentasi spontan jagung sehingga dapat dikembangkan kultur starter standar untuk proses fermentasi terkendali. Grits jagung direndam dalam air steril (grits : air $=1: 2, \mathrm{~b} / \mathrm{v}$ ) dalam wadah tertutup pada suhu kamar $\left( \pm 28^{\circ} \mathrm{C}\right)$ selama 72 jam untuk mensimulasi proses fermentasi spontan. Setelah 0 , 4 , 12, 24, 36, 48, 72 jam, sampel air dan grits jagung diambil untuk dianalisis jenis kapang, kamir, dan bakteri asam laktat (BAL) yang tumbuh. Isolat yang diperoleh dari fermentasi spontan diinokulasi kembali pada media yang sama dengan menambahkan pati untuk mengamati aktivitas amilolitiknya. Selanjutnya, masing-masing isolat diidentifikasi: kapang dengan metode slide culture, sementara kamir dan BAL dengan perangkat cepat biokimiawi berturut-turut API 20C AUX dan API CH50. Jumlah masing-masing mikroba diplotkan terhadap waktu untuk mendapatkan kurva pertumbuhan mikroba selama fermentasi spontan. Hasil penelitian menunjukkan bahwa mikroba yang tumbuh selama fermentasi spontan terdiri dari kapang Penicillium citrinum, P. chrysogenum, A. flavus, A. niger, Rhizopus stolonifer, R. oryzae, Fusarium oxysporum, Acremonium strictum, khamir Candida famata, Kodamaea ohmeri, Candida krusei/incospicua, serta bakteri asam laktat Lactobacillus plantarum 1a, Pediococcus pentosaceus, L. brevis 1, L. plantarum 1b, dan L. paracasei ssp paracasei 3. Empat kapang dan satu kamir bersifat amilolitik sementara tidak ada BAL yang bersifat amilolitik. Kurva pertumbuhan menunjukkan bahwa kapang dan kamir amilolitik tumbuh dan menghidrolisis pati selama fermentasi awal sementara BAL memanfaatkan produk hasil hidrolisis dan mendominasi tahap selanjutnya selama fermentasi.

Kata kunci: amilolitik, BAL, fermentasi spontan, jagung, kamir, kapang

Paper Presented at International Conference on "Future of Food Factors", SEAFAST, October 3-4 2012, Jakarta, Indonesia.

*Corresponding Author:

Email: ratihde@ipb.ac.id; Phone: 0251-8620517 


\section{INTRODUCTION}

Maize used to be an important staple food in Indonesia but has became less popular because of the inconvenience in its preparation. Traditionally, maize flour is made by soaking of the maize kernel in water followed by draining, grinding and drying. The length of the spontaneous fermentation occurred during soaking was reported to have influence in the physicochemical characteristics of the maize flour (Aini et al. 2010). Several studies on spontaneous fermentation of maize have been reported, such as in ogi production (Nago et al. 1998) and pozol (ben Omar and Ampe, 2000). During the fermentation, amylolytic, lipolytic, and proteolytic bacteria, molds as well as yeasts were isolated.

Presence of various microorganisms during fermentation were thought to affect the physicochemical properties of white maize flour produced (Aini et al. 2010). The spontaneous fermentation decreased the protein, fat, crude fiber, ash, starch, reducing sugar, $\mathrm{pH}$, bulk density, and fat absorption capacity of the flour produced, while increased the bulk angle, whiteness, and water absorption capacity. Aini et al. (2010) reported that fermentation for 24 hours reduced the gelatinization temperature from 82 to $76.2^{\circ} \mathrm{C}$. Meanwhile fermentation for 72 hours increased the gelatinization temperature of the maize flour to $85.2^{\circ} \mathrm{C}$. Fermentation for 48 hours increased the flour peak viscosity (648 BU), while 72 hours fermentation decreased its peak viscosity to $550 \mathrm{BU}$ which was similar to the unfermented flour. Fermentation for 12 to 60 hours increased the heat stability of the maize flour. Meanwhile, fermentation for up to 36 hours reduced the retrogradation tendency of the maize flour and soaking 48 hours increased the gel strength as compared to unfermented flour. The above results suggest that it is possible to control the fermentation process to achieve desired physicochemical properties of the maize flour. At the present, maize fermentation commonly rely on the naturally occuring microorganisme in the raw materials. Therefore, a consistent quality of the product may be difficult to achieve. The use of known microorganisms originated from the spontaneous fermentation is expected to better control the quality of the product. The study aims to isolate and identify microorganisms naturally growing during spontaneous fermentation of maize. The microorganisms isolated can be further used to design a starter culture for a controlled fermentation to produce maize flour with desired physicochemical characteristics.

\section{MATERIALS AND METHODS}

\section{Materials}

The maize used in this study was of Anoman type1 local variety obtained from the Cereal Crops Research Center Maros, Sulawesi. Maize grits was obtained by grinding using a pin disc mill followed by sievering with a shaker-siever.

\section{Spontaneous fermentation of maize grits}

Maize kernels were washed with sterile distilled water (kernel:water=1:4, w/v, 5 mins) and made into grits $( \pm 4 \mathrm{~mm}$ in diameter) by using pin disc mill. The resulting grits were then sieved by mesh siever 10 and the grits retained in the siever were collected. After that, grits were washed in sterile water (grits:water $=1: 4, w / v, 5$ mins), floating and unused part were discharged, and drained for 30 mins. Fermentation of the maize grits was carried out by soaking the grits with sterile water (grits:water $=1: 2 \mathrm{w} / \mathrm{v}$ ) in a covered container at room temperature $\left( \pm 28^{\circ} \mathrm{C}\right.$ ) for up to 72 hours (modified from Aini et al. 2010). Sampling was done at $0,4,12,24,36,48$, and 72 hours of fermentation.

\section{Enumeration of microorganisms (Nago et al. 1998)}

Samples of maize grits and water $(10 \mathrm{~g})$ were homogenized with $90 \mathrm{ml}$ of sterile peptone physiological saline solution. One $\mathrm{ml}$ of the appropriate dilution were plated onto media (a) Plate Count Agar (PCA, Oxoid) for total plate count (TPC), (b) de Man Rogosa and Sharpe Agar (MRSA, Oxoid) added with 0.5\% $\mathrm{CaCO}_{3}$ for LAB; (c) Yeast Extract Glucose Agar (YEGA, Oxoid) and $0.01 \%$ oxytetracyclin for yeasts and (d) Acidified Potato Dextrose Agar (APDA, Oxoid) for molds. Plates were incubated at $30^{\circ} \mathrm{C}$ for 24 hours for TPC and LAB, 48 hours for yeast and 5 days for mold. Enumeration for each visually distinct colony was quantified at all sampling times.

\section{Microbial isolation and identification (Nago et al. 1998)}

Any visually distinct bacterial, yeast or mold colony appearing on the plates was isolated and streaked onto the appropriate media until single colonies were obtained. The isolated bacterial colony was Gram stained, microscopically observed and tested for catalase activity. LAB isolates were further identified using API $50 \mathrm{CH}$. Yeast isolates were identified using API 20C AUX rapid kits. Individual mold isolate was streaked onto media APDA and Czapek Yeast Extract Agar (CYA) and incubated for $7 \times 24$ hours at 5,28 dan $37^{\circ} \mathrm{C}$. The color and diameter of the colonies were observed and recorded. The mold growth on the above media made into slide culture preparates on CYA and observed under microscope and the conidiophore types, metulae, phialide, and conidia forms were compared to these described in Pitt and Hocking (2009) and Samson et al. (1981). The amylolytic activity of the isolates was observed on MRS containing- $2 \%$ starch $+1 \%$ anyline blue for LAB; or YEGA containing- $2 \%$ starch for molds and yeasts.

\section{Determination of $\mathrm{pH}$ (AOAC, 1995)}

The $\mathrm{pH}$ of the media at various fermentation time was measured according to AOAC (1995).

\section{Enzyme activity (EC.3.2.1.1)}

The mixture of maize and water after $0,4,12,24,36,48$, and 72 hours of fermentation was centrifuged at $7000 \mathrm{rpm}$ at $4^{\circ} \mathrm{C}$ for $10 \mathrm{~min}$ and the substrate-free supernatant was used for estimation of enzyme activity. The amylase activity was determined by measuring the reducing sugar formed by the enzymatic hydrolysis of starch (EC.3.2.1.1). 


\section{RESULTS AND DISCUSSION}

\section{Growth of naturally occuring microorganisms during spontaneous fermentation}

During spontaneous fermentation for 72 hours, the total microorganisms grew from 4.3 to $8.7 \mathrm{log} \mathrm{CFU} / \mathrm{mL}$. In the first two hours the number of microorganisms remained constant suggesting an adaptation period (lag phase). This phase was followed by slow growth during 2-4 $\mathrm{h}$ and a rapid growth (log phase) during 4-12 hours of fermentation. After 12 hours the population reached stationary phase as shown by a plateau curve, during which a subset of the population underwent death phase, and concomitantly another group grew. Overall, there is an increase of microbial population of 4 log cycles throughout the 72 hours of fermentation process (Figure 1).

\section{The $\mathrm{pH}$ value}

During the first four hours of the fermentation, the $\mathrm{pH}$ of medium was relatively stable $(\mathrm{pH}$ 5.8-5.9). However, the $\mathrm{pH}$ experienced a sharp decline during 4-12 hours of fermentation, reaching a pH of 4.4 at 12 hours. The $\mathrm{pH}$ was relatively stable afterwards. During lag and early log phase fermentation (0-4 hours), $\mathrm{pH}$ did not change much due to lack of microbial metabolisms ( $\mathrm{pH}$ 5.8-5.9). The significant decrease in $\mathrm{pH}$ corresponds to the rapid growth of the microorganisms during fermentation (Figure 1).

\section{Microbial isolation and identification}

\section{Mold isolates}

During enumeration of the colonies, five visually distinct molds were observed. Initial identification suggested that molds growing during fermentation consisted of Penicillium sp, A. flavus, A. niger, Rhizopus sp, and Fusarium sp. Further identification based on slide culture suggested that the Penicillium consisted of 2 species i.e. amylolytic $P$. citrinum and non-amylolytic Penicillium chrysogenum, the Rhizopus consisted of non-amylolytic Rhizopus stolonifer and R.oryzae, while the Fusarium can be differentiated into amylolytic Acremonium strictum and non-amylolytic Fusarium oxysporum. Since the species of the three genuses can not be differentiated visually, the number of these species was reported as the corresponding genus (Figure 2). Description of all molds based on slide culture observation is presented in Table 1. An example of such observation can be seen in Figure 3 .

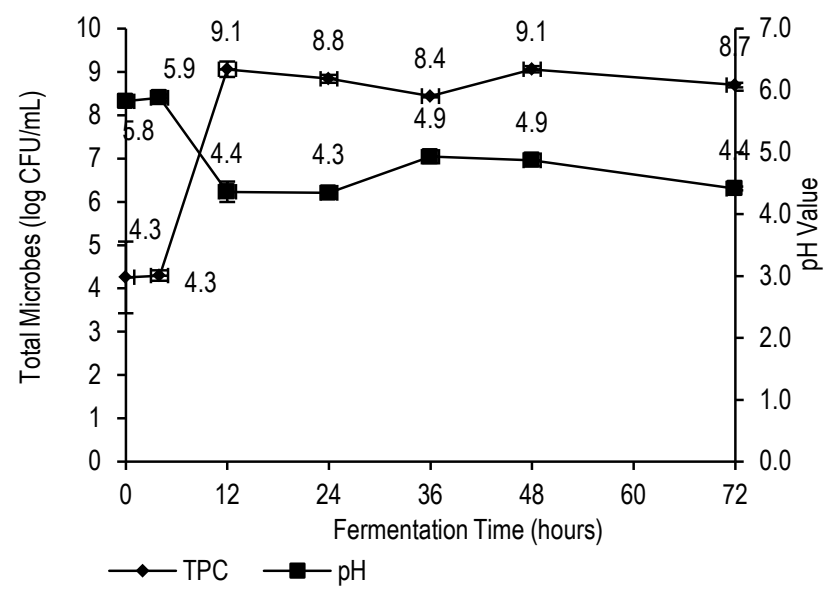

Figure 1. Total plate counts (TPC) of microorganisms and the $\mathrm{pH}$ changes during spontaneous fermentation of maize

Table 1. Description of molds growing during spontaneous fermentation maize grits

\begin{tabular}{|c|c|c|c|}
\hline $\begin{array}{l}\text { Visual Observation of } \\
\text { Colonies }\end{array}$ & Slide Culture Observation & Identification & Amylolytic Activity \\
\hline \multirow[t]{2}{*}{$\begin{array}{l}\text { White hypae, blue- } \\
\text { greenish spores }\end{array}$} & $\begin{array}{l}\text { Colonies are yellow-gray with diameter of } 27.7 \mathrm{~mm} \text { after } 7 \text { days incubation at room } \\
\text { temperature. When incubated at } 37^{\circ} \mathrm{C} \text { colonies are tosca green with } 25-32 \mathrm{~mm} \text { diameter. } \\
\text { Conidiophores have three-stage branch pattern. Metulae somewhat cylindrical with an } \\
\text { average number phialide } 5 . \text { Phialide looks like a flask. Conidia roundish shaped and } \\
\text { translucent. }\end{array}$ & $\begin{array}{l}\text { Penicillium } \\
\text { chrysogenum }\end{array}$ & Non-amylolytic \\
\hline & $\begin{array}{l}\text { Conidiophores have one-stage branch pattern which grow from the surface of hyphae. At } \\
\text { the top there are metulae with an average of } 3 \text {, growing spread. Phialides looks like a flask } \\
\text { with an average number } 6 \text {. Conidia are spherical and translucent. }\end{array}$ & $\begin{array}{l}\text { Penicillium } \\
\text { citrinum }\end{array}$ & Amylolytic \\
\hline $\begin{array}{l}\text { White hypae, blue- } \\
\text { greenish yellow spores }\end{array}$ & $\begin{array}{l}\text { Conidiophores are translucent. Vesicles are roundish in shape. Phialides grow directly on } \\
\text { the vesicle. Conidia are spherical and conidial heads have radiate type. }\end{array}$ & Aspergillus flavus & Amylolytic \\
\hline $\begin{array}{l}\text { White hypae, short, } \\
\text { gray to black spores }\end{array}$ & $\begin{array}{l}\text { Conidiophores are translucent. Vesicles are roundish. Phialides grow on the metulae. } \\
\text { Metulae are translucent. Conidia are spherical and conidial heads have radiate type. }\end{array}$ & Aspergillus niger & Amylolytic \\
\hline \multirow[t]{2}{*}{$\begin{array}{l}\text { White hypae, long, } \\
\text { grays and black spore }\end{array}$} & $\begin{array}{l}\text { Sporangiophore are tall, mostly grown on their own. Sporangium are rounded, rounded- } \\
\text { oval columella, and elliptical sporangiospore. There are branched rhizoid and no } \\
\text { clamydospora. There are long stolon that connected sporangiophore. }\end{array}$ & $\begin{array}{l}\text { Rhizopus } \\
\text { stolonifer. }\end{array}$ & Non-amylolytic \\
\hline & $\begin{array}{l}\text { Sporangiophore mostly grown on their own. The sporangiospore grows directly from the } \\
\text { stolon without rhizoid. Sporangium are roundish shape. Clamydospora are oval and } \\
\text { columella are rounded shape. }\end{array}$ & Rhizopus oryzae & Non-amylolytic \\
\hline \multirow[t]{2}{*}{$\begin{array}{l}\text { White hypae, pink and } \\
\text { orange }\end{array}$} & $\begin{array}{l}\text { Mycelium grow sparsely and pink colored after } 24 \text { hours incubation at room temperature. } \\
\text { After } 48 \text { hours incubation, mycelium are purple. Conidia have septat. Phialids are oval- } \\
\text { shaped. Conidiophores have a short branch and there are chlamydospora. }\end{array}$ & $\begin{array}{l}\text { Fusarium } \\
\text { oxysporum }\end{array}$ & Non-amylolytic \\
\hline & $\begin{array}{l}\text { Colonies are orange with a diameter of } 13-17 \mathrm{~mm} \text { after } 7 \text { days incubation at } 37^{\circ} \mathrm{C} \text {. } \\
\text { Conidiophores are simple and not branched. Phialides are slender and unbranched which } \\
\text { grow at slightly fasciculate aerial hyphae. Slimy head are rounded-ellips and translucent } \\
\text { which contain conidia. }\end{array}$ & $\begin{array}{l}\text { Acremonium } \\
\text { strictum }\end{array}$ & Amylolytic \\
\hline
\end{tabular}




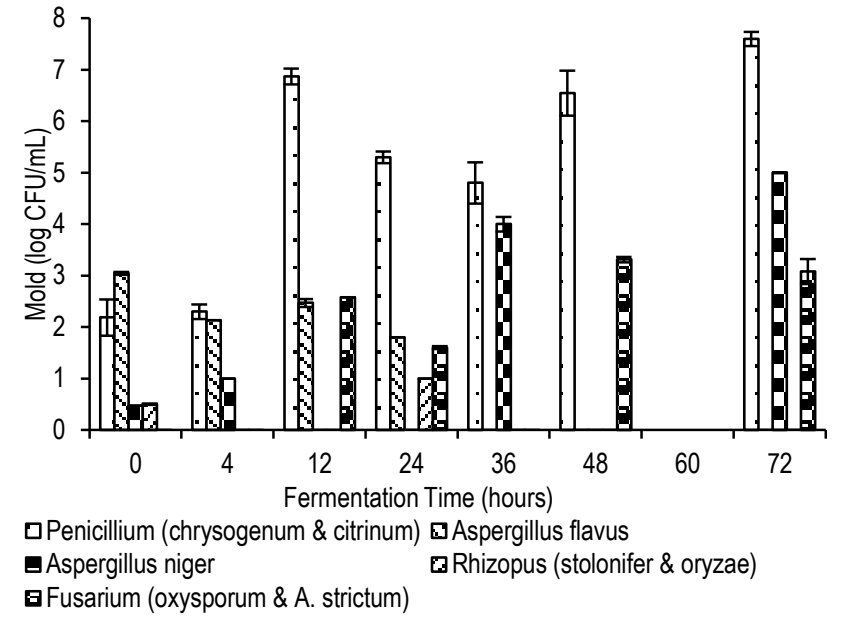

Figure 2. Mold growth during spontaneous fermentation of maize
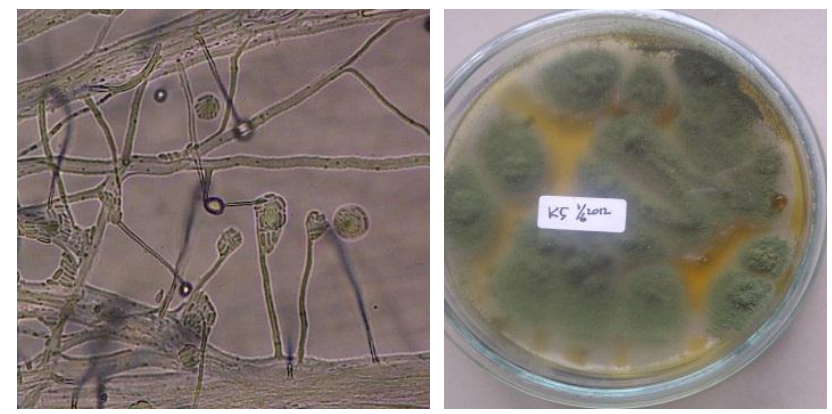

Figure 3. An example of microscopic observation of mold slide culture identified as Acremonium strictum

Figure 2 shows that Penicillium and Fusarium were isolated throughout the fermentation process. For Penicillium and Fusarium, each had two peaks of growth. Very likely the first peaks were amylolytic $P$. citrinum and Acremonium strictum while the following growth curves belongs to the non-amylolytic $P$. chrysogenum and $F$. oxysporum.

Penicillium citrinum is mesophillic and grows at $5-40^{\circ} \mathrm{C}$ with optimum temperatures of $26-30^{\circ} \mathrm{C}$. It grows at $\mathrm{pH} \mathrm{2-10} \mathrm{with}$ optimum $\mathrm{pH}$ between 5-7. This mold is also xerophillic and grows at aw $0.80-0.84$. Penicillium citrinum can produce a toxin, citrinin, at $15-37^{\circ} \mathrm{C}$ with the optimum temperature of $30^{\circ} \mathrm{C}$ (Sweeney and Dobson, 1998). Citrinin, also known as a yellow rice toxin (Pitt and Hocking, 2009) is found in rice (Kumar, 2008). Penicillium chrysogenum is commonly found in maize. The mold is an endophyte which is widespread in nature and is often found living on food and indoor environment. This mold can produce antibiotics such as penicillin, chrysogine, xanthocillins, secalonic acids, sorrentanone, and PR-toxin (Meng, 2011; van den Berg, 2010).

The main source of Acremonium strictum is maize, but it can be found in black bean seeds, raw cork, wheat, barley, rice, bananas with crown rot, fresh vegetables, peanuts, pecans, hazelnuts and walnuts, soybeans, frozen meat, salami and biltong. A. strictum and other Acremonium species encountered in foods are not known to produce mycotoxins (Pitt and Hocking, 2009). Acremonium strictum as an endophytic fungi benefits from the host plant, i.e. nourishment, water, and physical protection against biotic and abiotic adversities. Meanwhile, the host plant may be protected by the endophyte that produce secondary metabolites, e.g. alkaloids, antibiotics, or toxins that may be toxic to pathogenic fungi (D'amico et al. 2008). Wicklow et al. (2005) reported that $A$. strictum, also known as Acremonium zeae is antagonistic to kernel rotting and mycotoxin producing fungi $A$. flavus and Fusarium verticillioides in cultural tests for antagonism, and interferes with $A$. flavus infection and aflatoxin contamination of preharvest maize kernels.

Fusarium oxysporum is known to produce trichothecenes which have been linked to alimentary toxic aleukia, fusariotoxicoses and are cytotoxic to mammalian cells. These toxins are produced at the optimal growth conditions for Fusarium (Sweeney and Dobson, 1998). The average concentration of trichotheces found in maize is $226.2 \mu \mathrm{g} / \mathrm{kg}$ and ranging from 9.6-745.1 $\mu \mathrm{g} / \mathrm{kg}$ (Adejumo et al. 2007).

Both Aspergilli were amylolytic but $A$. niger seemed to grow throughout the fermentation process while $A$. flavus grew well in the first 24 hours and decline afterward. This observation suggested that $A$. flavus was not a good competitor and $A$. niger as well as other microorganisms may have over grown $A$. flavus. This phenomenon is good with regard to food safety because inhibition of $A$. flavus is expected to decrease the aflatoxin production during fermentation. Purwijantiningsih et al. (2005) found that Rhizopus oligosporus dan Candida can inhibit the growth of $A$. flavus (37.21\%) and aflatoxin production (99.96\%). Recent study in East Java, Indonesia, showed that aflatoxins were found in $30 \%$ of maize at farmer level at the concentrations of more than $20 \mathrm{ppb}$ and $10 \%$ of maize contains aflatoxin more than $100 \mathrm{ppb}$. At the trader level, the frequency of finding the toxin in maize was even higher, i.e. $45 \%$ of maize contain aflatoxin more than 20 ppb with $18 \%$ contain more than $100 \mathrm{ppb}$ of aflatoxins (Rahayu, 2008). Unfortunately, A. niger is also known to produce other mycotoxin, i.e. ochratoxin A (OTA) at $15-40^{\circ} \mathrm{C}$ which could lead to nephrotoxin. OTA's production is low at aw 0.92 and temperature $25-40^{\circ} \mathrm{C}$ (Alborch et al. 2011).

According to Sweeney and Dobson (1998), Fusarium, Aspergillus and Penicillium are commonly found as contaminants in cereals and legumes during drying and storage. Kaaya and Kyamuhangire (2006) also isolated Aspergillus, Fusarium, Penicillium, and Rhizopus in dried and stored maize. Amusa et al. (2005) also reported that during spontaneous fermentation of maize and soybeans for the making of ogi, $A$. niger, A. flavus, Fusarium oxysporum, and Rhizopus stolonifer were found. Pitt and Hocking (2009) stated that Fusarium sp, and Penicillium sp were commonly found in preharvest maize, while $A$. flavus can be found in preharvest maize and during storage.

Maize is a good substrate for mold growth because it contains high protein and carbohydrate needed for mold growth (Alborch et al. 2011). Generally maize has moisture contents of $10.4-15.1 \%$ at $12-40^{\circ} \mathrm{C}$. When stored at ambient temperature, maize will support $A$. flavus and $A$. niger that grow well at 32$33^{\circ} \mathrm{C}$ and $25-40^{\circ} \mathrm{C}$, Penicillium sp at $26-30^{\circ} \mathrm{C}$, Fusarium sp at $24-26^{\circ} \mathrm{C}$ (Sweeney and Dobson, 1998). Meanwhile $R$. stolonifer 
and $R$. oryzae's optimum growth are at $25^{\circ} \mathrm{C}$ (Ramos-Gracia et al. 2012) and $37^{\circ} \mathrm{C}$ (Pitt and Hocking, 2009), respectively.

Both Rhizopus were non amylolytic and grew in low number during fermentation. Amusa et al. (2005) reported the presence of Rhizopus sp in white maize (10.5\%) and yellow maize (9.5\%). $R$. oryzae has cellulase, xylanase, pectinase, tannase, protease, phytase and lypase activities (Ghosh and Ray, 2011) which probably explains the low number of the mold when competing with various amylolytic mold presence. $R$. stolonifer is not pathogenic (Pitt and Hocking, 2009), but causes rot in fruits (Hahn et al. 2004).

Growth of amylolytic Fusarium, Aspergilli and Penicillium resulted in carbohydrate hydolysis to produce simpler sugar. This will trigger growth of the successive molds of $P$. chrysogenum, F. oxysporum, and Rhizopus. This overal process is expected to influence the quality of the maize, especially with regard to its digestibility.

\section{Yeast isolates}

Isolation of yeast in YEGA resulted in four visually distinct colonies (Table 2). However, biochemical identification suggested that the four isolates belong to three species, i.e. Candida famata, Kodamaea ohmeri, and Candida krusei or $C$ incospicua (Figure 4).

Table 2. Description of yeasts isolated during spontaneous fermentation of maize grits

\begin{tabular}{llll}
\hline Morphology Characteristics & $\begin{array}{c}\text { Amylolytic } \\
\text { Activity }\end{array}$ & $\begin{array}{c}\text { API } \\
\text { Identification }\end{array}$ & $\%$ ID \\
\hline $\begin{array}{l}\text { Round-shaped, white, } \\
\text { mucous, surface is dull }\end{array}$ & Amylolytic & $\begin{array}{l}\text { Candida } \\
\text { famata }\end{array}$ & 92.8 \\
$\begin{array}{l}\text { Round-shaped, serrated at } \\
\text { the edges, cream, mucous, }\end{array}$ & Non- amylolytic & $\begin{array}{l}\text { Kodamaea } \\
\text { ohmeri }\end{array}$ & 94.7 \\
$\begin{array}{l}\text { surface is dull } \\
\begin{array}{l}\text { Round-shape with growing } \\
\text { spread, creamy-white, } \\
\text { mucous, surface is dull }\end{array}\end{array}$ & Non- amylolytic & $\begin{array}{l}\text { Candida } \\
\text { krusei/incosp } \\
\text { icua }\end{array}$ & 98.9 \\
\hline
\end{tabular}

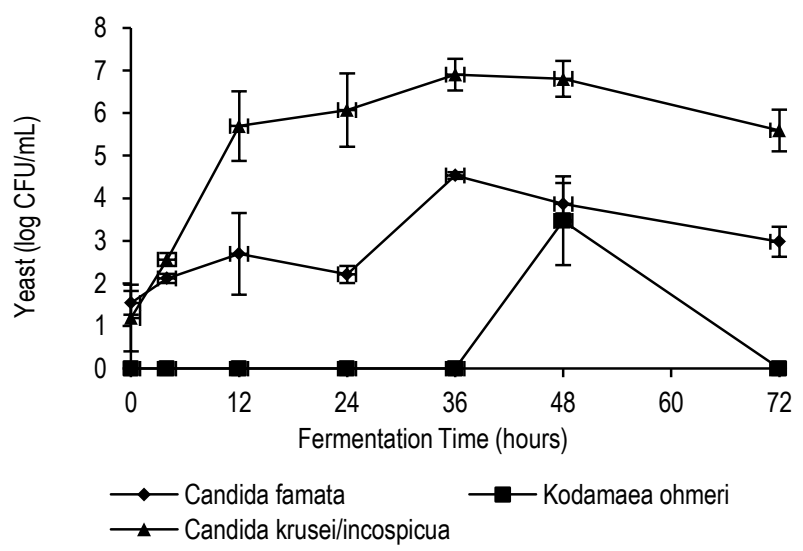

Figure 4. Yeast growth during spontaneous fermentation of maize

Growth of yeast and LABs are commonly observed in naturally fermented maize, such as those during the production of ogi, kenkey, mawe, and mahewu, traditional foods of of West Africa. These microorganisms are reported to play important role in aroma and flavor production as well as the stability of the final products. LABs and yeast affect the taste and structure of the dough in kenkey making (Omemu et al. 2007).
C. krusei is commonly isolated during maize fermentation. Nago et al. (1998) reported that during the fermentation of ogi, yeasts (7 log CFU/g) consisting of Candida krusei and $C$. humicola (41\%) as well as Geotricum spp. (26\%) were found. Omemu et al. (2007) isolated Candida krusei, Saccharomyces cerevisiae, Candida tropicalis, Geotrichum candidum, G. fermentans, Rhodotorula graminis on maize fermentation for making ogi. Candida krusei can live in the presence of lactic acid because it has a high tolerance to lactic acid (Halm et al. 2004). In addition C. krusei can stimulate the growth of $L$. plantarum and found in fermented maize for ogi production that has lipase and esterase activity that may contribute the final flavor of food (Omemu et al. 2007). In this study of C. krusei grew well and the number was higher than the other two yeasts.

Candida famata is usually found in plant and soil (Chaturvedi, 2003), dairy product especially cheese (Jacques and Casaregola, 2008) and Moroccan sourdough (Mohamed et al. 2007). Candida famata isolated from Moroccan sourdough shows high glucoamylase activity and produces biomass. This amylolytic yeast however did not grow as well as C. krusei. It has been reported that the yeast also exhibited lipolytic and proteolytic activities (Wojtatowicz et al. 2001).

Kodamaea ohmeri, previously known as Pichia ohmeri or Yamadazyma ohmeri, is a yeast within the family of Saccharomy cetaceae. K. ohmeri is the teleomorphic form of Candida guilliermondii and is widely used for the fermentation of fruit, pickles, and rinds (Yang et al. 2009).

\section{Lactic acid bacteria}

Identification of $L A B$ isolates using $A P I 50 C H$ rapid kit suggest that the the isolates were Lactobacillus plantarum1a, Pediococcus pentosaceus, Lactobacillus brevis 1, Lactobacillus plantarum 1b, and Lactobacillus paracasei ssp paracasei 3. All $\mathrm{LABs}$ were not capable of degradating starch. Description of the characteristics of $L A B$ isolated during spontaneous fermentation of maize is presented in Table 3 and Figure 5.

Table 3. Identification and characteristics of LABs isolated during spontaneous maize fermentation

\begin{tabular}{|c|c|c|}
\hline Morphological Characteristics & API Identification & $\%$ ID \\
\hline $\begin{array}{l}\text { Round-shaped, creamy white, } \\
\text { mucous, embossed on the surface of } \\
\text { the media, shiny }\end{array}$ & $\begin{array}{l}\text { Lactobacillus } \\
\text { plantarum1a }\end{array}$ & 99.9 \\
\hline Oval-shaped, white, mucous & $\begin{array}{l}\text { Pediococcus } \\
\text { pentosaceus }\end{array}$ & 96.9 \\
\hline $\begin{array}{l}\text { Round shaped, white mucus, growing } \\
\text { in the center of the media }\end{array}$ & Lactobacillus brevis1 & 73.4 \\
\hline Half-round shaped, white, mucous & $\begin{array}{l}\text { Lactobacillus } \\
\text { plantarum1b }\end{array}$ & 54.2 \\
\hline A small oval-shaped, white, mucous & $\begin{array}{l}\text { Lactobacillus paracasei } \\
\text { ssp paracasei3 }\end{array}$ & 99.3 \\
\hline
\end{tabular}

Lactic acid bacteria are the predominant bacteria found in the fermentation of maize products. Nago et al. (1998) reported that during the fermentation of ogi, maize flour is immersed in water for $1-3$ days at $25-35^{\circ} \mathrm{C}$ and lactic acid bacteria consisting of Lactobacillus fermentum cellobiosus, $L$. brevis and $L$. fermentum spp grow up to 9 log CFU/g. Other researcher isolated L. plantarum, Saccaharomyces cerevisiae, Candida crusei, C. tropicalis, Geotrichum candidum, G. fermentans, and Rhodotorula graminis during ogi fermentatin (Omemu et al. 2007). 
$L A B$ is also found in Pozol and reach 7-8 logs CFU/g during the first day of fermentation, 9 logs $\mathrm{CFU} / \mathrm{g}$ the second day and then decline to 8 logs CFU/g on the third day. During fermentation of ogi, Streptococus sp (25-75\%) and L. fermentum were isolated in the first 2 days and followed by $L$. plantarum, $L$ casei, L. delbruekii (ben Omar and Ampe, 2000).

This study shows that all LABs are non amylolytic, however they grew well throughout the fermentation process and maintained viability until 72 hours of fermentation. Presence of LABs may also contribute to the decrease in A. flavus. Edema and Sanni (2008) reported that LABs ( $L$ plantarum, $L$ brevis, $L$. fermentum, $L$. acidophilus) and yeasts (Pediococcus acidilactici, Leuconostoc mesenteroides, Leuconostoc dextranicum and Saccharomyces cerevisiae) isolated from spontaneously fermented maize can inhibit the growth of $A$. flavus.

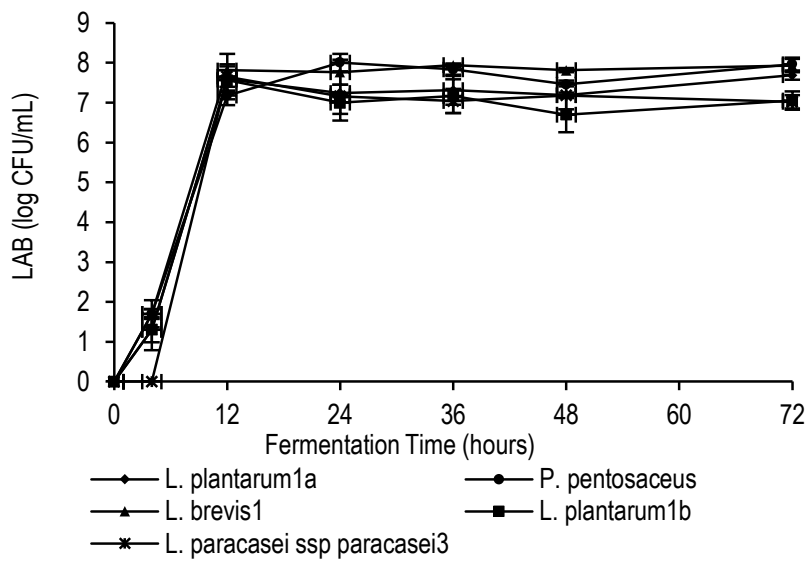

Figure 5. Growth of LABs (log CFU/mL) during spontaneous fermentation of maize

\section{Amylase activity}

The amylase activity observed during the spontaneous fermentation of maize grits shows similar pattern with the growth of amylolytic microorganisms. The amylolytic molds and yeast grew at the beginning of fermentation and hydrolyzed starch into simple sugars, which was used by the non-amylolytic organisms. The highest amylase activity was found at 12 hours fermentation (1.7 unit/mL.min), and the activity declined afterward (0.7 unit/mL.min) at 72 hours fermentation (Figure 6). The dominance of the lactic acid generated by LAB possibly led to the decrease in mold growth, thus decrease the amylolytic activity.

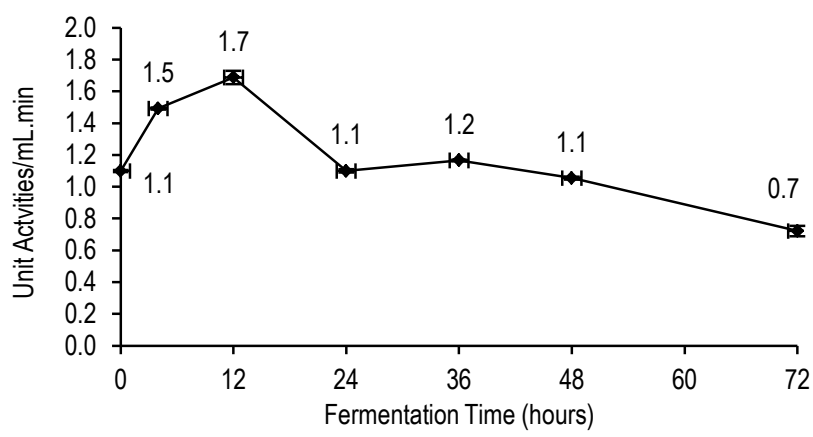

Figure 6. Changes in amylase activity during spontaneous fermentation of maize

\section{CONCLUSION}

Eight species of molds, three species of yeasts, and five species of $L A B$ grew sequentially during spontaneous fermentation of maize grits. Four of the eight mold isolates and one of three yeast isolates were amylolytic, i.e. P. citrinum, A. flavus, $A$. niger, Acremonium strictum, and Candida famata. Non amylolytic molds and yeasts that grew during the spontaneous fermentation of maize were $P$. chrysogenum, $R$. oryzae, $R$. stolonifer, F. oxysporum, Kodamaea ohmeri and Candida krusei or C. incospicua. Five non amylolytic species of LAB were Lactobacillus plantarum 1a, Pediococcus pentosaceus, Lactobacillus brevis 1, Lactobacillus plantarum 1b, Lactobacillus paracasei ssp paracasei3.

Based on the growth curves, it was very likely that amylolytic mold such as $P$. citrinum, A. flavus, A. niger, Acremonium strictum, and Candida famata grew and hydrolized starch during the course of fermentation. Non amylolytic microorganisms grew later on the fermentation benefiting from the hydrolyzed products. The amylolytic activity in the early fermentation was high and decreases with longer fermentation time.

\section{ACKNOWLEDGEMENT}

The authors would like to acknowledge the Indonesian Center for Agricultural Post Harvest Research \& Development (ICAPRD), Bogor, Indonesia for funding of this research through the Agricultural Research Partnership program in 2011.

\section{REFERENCES}

Adejumo TO, Hettwer U, Karlovsky P. 2007. Occurrence of Fusarium species and trichothecenes in Nigerian maize. Int J Food Microbiol 116: 350-357. DOl: 10.1016/.i.jfoodmicro. 2007.02.009.

Aini N, Hariyadi P, Muchtadi TR, Andarwulan N. 2010. Hubungan antara waktu fermentasi grits jagung dengan sifat gelatinisasi tepung jagung putih yang dipengaruhi ukuran partikel. J Teknol dan Industri Pangan 21: 18-24.

Alborch L, Bragulat MR, Abarca ML, Cabañes FJ. 2011. Effect of water activity, temperature and incubation time on growth and ochratoxin A production by Aspergillus niger and Aspergillus carbonarius on maize kernels. Int $\mathrm{J}$ Food Microbiol 147: 53-57. DOl: 10.1016/i.iffoodmicro.2011.03. 005.

Amusa NA, Ashya OA, Oladapo MO. 2005. Microbiological quality of ogi and soy-ogi (a Nigerian fermented cereal porridge) widely consumed and notable weaning food in southern Nigeria. J Food Agric Environ 3: 81-83.

[AOAC] Association of Official Analytical Chemists. 1995. Official Methods of Analysis of the Association Analytical Chemistry Inc, Washington D.C. 
ben Omar N, Ampe F. 2000. Microbial community dynamics during production of the Mexican fermented maize dough pozol. Appl Environ Microb 66: 3664-3673.

Chaturvedi V. 2003. Mycology Proficiency Testing Program January 2003. Wadsworth Center New York State Department of Health.

D'amico M, Frisullo S, Cirulli M. 2008. Endophytic fungi occurring in fennel, lettuce, chicory, and celery-commercial crops in southern Italy. Mycol Res 112: 100-107. DOl: 10.1016/j.mycres.2007.11.007.

Edema MO, Sanni Al. 2008. Functional properties of selected starter cultures for sour maize bread. Food Microbiol 25: 616-625. DOI: 10.1016/i.fm.2007.12.006.

Ghosh B, Ray RR. 2011. Current commercial perspective of Rhizopus oryzae: A Review. J Appl Sci 11: 2470-2486. DOl: 10.3923/jas.2011.2470.2486.

Hahn F, Lopez I, Hernandez G. 2004. Spectral detection and neural network Discrimination of Rhizopus stolonifer spores on red tomatoes. Biosyst Eng 89: 93-99 DOl: 10.1016/.j.biosystemseng.2004.02.012.

Halm M, Hornbæk T, Arneborg N, Sefa-Dedeh S, Jespersen L. 2004. Lactic acid tolerance determined by measurement of intracellular $\mathrm{pH}$ of single cells of Candida krusei and Saccharomyces cerevisiae isolated from fermented maize dough. Int J Food Microbiol 94: 97-103. DOI: 10.1016/i. ijfoodmicro.2003.12.019.

Jacques N, Casaregola S. 2008. Safety assessment of dairy microorganisms: The hemiascomycetous yeasts. Int J Food Microbiol 126: 321-326. DOI: 10.1016/j.ijfoodmicro.2007. $\underline{08.020 .}$

Kaaya AN, Kyamuhangire W. 2006. The effect of storage time and agroecological zone on mould incidence and aflatoxin contamination of maize from traders in Uganda. Int J Food Microbiol 110: 217-223. DOI: 10.1016/j.ijfoodmicro.2006. 04.004.

Kumar M, Dwivedi P, Sharma AK, Telang AG, Patil RD, Singh ND. 2008. Immunotoxicity of ochratoxin $A$ and citrinin in New Zealand white rabbits. World Rabbit Sci 16: 7-12. DOl: 10.4995/wrs.2008.641.

Meng L, Sun P, Tang H, Li L, Draeger S, Schulz B, Krohn K, Hussain H, Zhang W, Yi Y. 2011. Endophytic fungus Penicillium chrysogenum, a new source of hypocrellins. Biochem Syst Ecol 39: 163-165. DOl: 10.1016/..bse.2011. 02.003.

Mohamed L, Zakaria M, Ali A, Senhaji W, Mohamed O, Mohamed E, Berny EL Hassan, Mohamed J. 2007. Optimization of growth and extracellular glucoamylase production by Candida famata isolate. Afr $\mathrm{J}$ Biotechnol 6 : 2590-2595.

Nago MC, Hounhouigan JD, Akissoe N, Zanou E, Mestres C. 1998. Characterization of the Beninese traditional Ogi, a fermented maize slurry: Phisicochemical and Microbiological aspects. Int J Food Sci Tech 33: 307-315. DOl: 10.1046/j.1365-2621.1998.00169.x.

Omemu AM, Oyewole OB, Bankole MO. 2007. Significance of yeasts in the fermentation of maize for ogi production. Food Microbiol 24: 571-576. DOI: 10.1016/i.fm.2007.01.006.

Pitt JI, Hocking AD. 2009. Fungi and Food Spoilage. Springer.

Purwijantiningsih E, Dewanti-Hariyadi R, Nurwitri CC, and Istiana. 2005. Penghambatan produksi aflatoksin dari Aspergillus flavus oleh kapang dan kamir yang diisolasi dari ragi tempe. Biota 10: 146-153.

Rahayu ES. 2008. Mengantisipasi kontaminasi mikotoksin. Food Rev Indonesia 3: 28-30.

Ramos-García M, Bosquez-Molina E, Hernández-Romano J, Zavala-Padilla G, Terrés-Rojas E, Alia-Tejacal I, BarreraNecha L, Hernández-López M, Bautista-Baños S. 2012. Use of chitosan-based edible coatings in combination with other natural compounds, to control Rhizopus stolonifer and Escherichia coli DH5a in fresh tomatoes. Crop Prot 38: 1-6. DOI: 10.1016/i.cropro.2012.02.016.

Samson RA, Hoekstra ES, van Oorschot CAN. 1981. Introduction to Food-Borne Fungi. Institute of The Royal Netherlands Academy of Arts and Sciences.

Sweeney MJ, Dobson ADW. 1998. Mycotoxin production by Aspergillus, Fusarium and Penicillium Species. Int J Food Microbiol 43: 141-158. DOI: 10.1016/S0168-1605(98) 00112-3

van den Berg MA, 2010. Functional characterisation of penicillin production strains. Fungal Biology reviews 24: 73-78. DOl: 10.1016/j.fbr.2010.03.006.

Wicklow DT, Roth S, Deyrup ST, Gloer JB. 2005. A protective endophyte of maize: Acremonium zeae antibiotics inhibitory to Aspergillus flavus and Fusarium verticillioides. Mycol Res 109: 610-618. DOI: 10.1017/S0953756205002820.

Wojtatowicz M, Chrzanowska J, Juszczyk P, Skiba A, Gdula A. 2001. Identification and biochemical characteristics of yeast microflora of Rokpol cheese. Int J Food Microbiol 69: 135140. DOI: 10.1016/S0168-1605(01)00582-7.

Yang BH, Peng MY, Hou SJ, Sun JR, Lee SY, Lu JJ. 2009. Fluconazole-resistant Kodamaea ohmeri fungemia associated with cellulitis: Case report and review of the literature. Int $\mathrm{J}$ Infect Dis 13: e493-e497. DOI: 10.1016/j.ijid.2009.02.003. 